\title{
KEDUDUKAN ANAK MENURUT HUKUM POSITIF DI INDONESIA
}

\author{
Saadatul Maghfira \\ Fakultas Syariah IAIN Batusangkar \\ J1. Sudirman No. 137 Kuburajo Lima Kaum Batusangkar \\ e-mail: saadatulmaghfira@gmail.com
}

\begin{abstract}
Undang-undang Nomor 23 Tabun 2002 which is revised by Undang-undang Nomor 35 Tabun 2014 about child protection chapter 1 verse 1 points out that child are those who are under 18 years old, including the fetus. Those laws regulate the position of children in the law and their rights as well, and parents' responsibilities toward their children. Chapter 42-49 of UndangUndang Nomor 1 Tabun 1974 points out that child's positions can be classified into two categories, namely legal and illegal child depending upon the ways their parents get married. If their parents' married has fulfilled marital requirements both in terms of religion and law implemented in Indonesia the child resulted from this marriage is categorized into legal child. Conversely, if a child was born from parents whose marriage does not fulfill the requirements, the child, therefore, belongs to illegal child categories. Civil law in Indonesia has regulated rights a child deserves as stated in Undang-Undang Republik Indonesia Nomor 4 tabun 1979 concerning with Child Prosperity found in Chapter II and Undangundang Nomor 23 Tahun 2002 jo Undang Undang Nomor 35 Tabun 2014 that covers rights to live, to be non discriminative, to have identity, to be treated fairly, and so forth in line with parents' responsibilities toward children so that they are treated properly and live prosperously
\end{abstract}

Kata kunci: anak, hukum positif, Indonesia

\section{PENDAHULUAN}

P ada dasarnya Allah telah menggariskan 2 bahwa manusia itu dihiasi oleh nafsu yaitu senang pada wanita dan senang pada anak atau keturunan. Firman Allah dalam Q.S. Ali Imran ayat 14 :

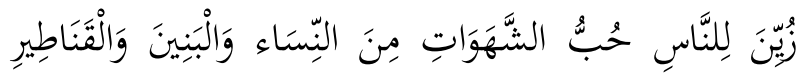

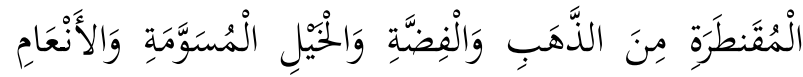

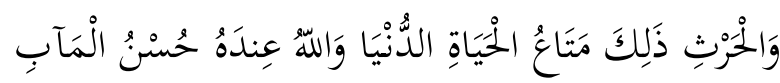

Dijadikan indah pada (pandangan) manusia kecintaan kepada apa-apa yang diingini, yaitu: wanita-wanita, anak-anak, harta yang banyak dari jenis emas, perak, kuda pilihan, binatang-binatang ternak dan sawah ladang. Itulah kesenangan hidup di dunia, dan di sisi Allah-lah tempat kembali yang baik (surga) (Q.S. Ali Imran [3]: 14) (Departemen Agama RI, 2002: 159).

Maka dapat dipahami dari kebutuhan dasar dan tuntutan biologis itu manusia memerlukan perkawinan. Karena melalui perkawinan dapat diharapkan terpenuhinya keinginan untuk mempertahankan diri dan tersalurnya kecintaan terhadap wanita dan anak. Perkawinan yang dilakukan oleh orang tua sangat menetukan tentang status seorang anak, Pasal 42 Undang-undang Nomor 1 Tahun 1974 menyebutkan "Anak yang sah adalah anak yang dilahirkan dalam atau sebagai akibat perkawinan yang sah", Sedangkan dalam pasal 99 Kompilasi Hukum Islam Tahun 1991 dijelaskan “Anak sah 
adalah : a. Anak yang dilahirkan dalam atau akibat perkawinan yang sah. b. Hasil pembuahan suami isteri yang sah di luar rahim dan dilahirkan oleh istri tersebut" (Andi, 2008:1).

Dari Pasal 42 Undang-Undang No. 1 Tahun 1974 di atas dapat ditarik kesimpulan apabila perkawinan dilaksanakan dengan melalaikan ketentuan agama, maka perkawinan itu disebut perkawinan yang tidak sah, dan hal ini pun akan berimbas kepada kedudukan keturunan yang dihasilkan dari perkawinan tersebut, yakni anak yang tidak sah. Undangundang Nomor 1 Tahun 1974 menyatakan Keadaan di atas tentu akan sangat menyedihkan mengingat anak adalah amanah sekaligus karunia Allah Swt yang harus senantiasa dijaga dan dilindungi karena dalam diri anak melekat harkat, martabat, hak-hak sebagai manusia yang harus dijunjung tinggi.

Hak asasi anak merupakan bagian dari hak asasi manusia yang termuat dalam UndangUndang Dasar 1945 dan Konferensi Perserikatan Bangsa-Bangsa tentang Hak-Hak Anak. Dilihat dari sisi kehidupan berbangsa dan bernegara, anak adalah pewaris dan sekaligus potret masa depan bangsa di masa datang, generasi penerus cita-cita bangsa, sehingga setiap anak berhak atas kelangsungan hidup, tumbuh, dan berkembang, berpartisipasi serta berhak atas perlindungan dari tindak kekerasan dan diskriminasi serta hak sipil dan kebebasan (Mulyadi, 2005:3-4).

\section{METODE PENELITIAN}

Jenis penelitian yang digunakan dalam tulisan ini adalah penelitian hukum normatif (Normatif Legal Research). Penelitian hukum normatif adalah penelitian hukum yang dilakukan dengan cara meneliti bahan pustaka dan data sekunder belaka. Penelitian hukum normatif ini juga disebut penelitian hukum doktriner, juga disebut sebagai penelitian perpustakaan atau studi dokumen. Disebut penelitian doktriner karena penelitian ini dilakukan dan ditujukan hanya pada peraturanperaturan yang tertulis atau bahan-bahan hukum yang lain. Sedang disebut sebagai penelitian perpustakaan ataupun studi dokumen disebabkan penelitian ini lebih banyak dilakukan terhadap data yang bersifat sekunder. Data yang diambil berkaitan dengan peraturan perundangundangan yang mengatur tentang masalah perlindungan anak dan hal-hal terkait lainnya dianalisis dengan menggunakan metode berfikir induktif.

\section{PEMBAHASAN}

\section{Pengertian Anak}

Anak merupakan mahkluk yang membutuhkan pemeliharaan, kasih sayang dan tempat bagi perkembangannya. Selain itu anak merupakan bagian dari keluarga, dan keluarga memberikan kesempatan bagi anak untuk belajar tingkah laku yang penting untuk perkembangan yang cukup baik dalam kehidupan bersama. Di dalam undang-undang Nomor 23 Tahun 2002 yang di perbaharui dengan Undang-undang Nomor 35 Tahun 2014 tentang perlindungan anak pasal 1 ayat 1 menyebutkan bahwa pengertian anak adalah seseorang yang belum berusia 18 (delapan belas ) tahun, termasuk anak yang masih dalam kandungan.

Sedangkan kalau ditinjau dari segi yuridis pengertian "anak" di mata hukum positif Indonesia lazim diartikan sebagai orang yang belum dewasa(Inminderjarigheid/person under age), orang yang di bawah umur/ keadaan di bawah umur (minderjaringheid/inferiority) atau kerap juga disebut sebagai anak yang di bawah pengawasan wali (minderjarige ondervoordij) (Mulyadi, 2005:3-4)

Dalam Undang-Undang Republik Indonesia Nomor 4 tahun 1979 tentang Kesejahteraan Anak pada Bab I (ketentuan umum), dijelaskan pada pasal 1 ayat 2 dijelaskan pengertian anak adalah seseorang yang belum 
mencapai umur 21 (dua puluh satu) tahun dan belum pernah kawin. (Sumiarni, 2000: 15)

Dalam penjelasan ayat 2 dari undangundang ini menyebutkan batas umur 21 (dua puluh satu) tahun ditetapkan oleh karena berdasarkan pertimbangan kepentingan usaha kesejahteraan sosial, kematangan pribadi, dan kematangan mental seorang anak dicapai pada umur tersebut. Namun menurut ketentuan undang-undang tersebut batas umur 21 (dua puluh satu) tahun tidak mengurangi ketentuan batas umur dalam peraturan perundangundangan lainnya, dan tidak pula mengurangi kemungkinan anak melakukan perbuatan sejauh ia mempunyai kemampuan untuk itu berdasarkan hukum yang berlaku. (Sumiarni, 2000: 21)

Sedangkan di dalam Islam tidak terdapat patokan usia untuk dapatnya seseorang disebut sebagai anak. Islam hanya mengenal istilah baligh untuk menyebut seseorang yang telah dewasa. Dan hal itu pada wanita ditandai dengan datangnya haid, sedangkan pada seorang lakilaki ditandai dengan mengalami mimpi basah. Dengan demikian selama seorang wanita/lakilaki belum mengalami tanda-tanda di atas dapat dikatakan ia masih anak-anak, sehingga belum dikenakan hukum.

Dalam bahasan ini penulis lebih cenderung memakai Undang-Undang Nomor 23 Tahun 2002 jo Undang-undang Nomor 35 Tahun 2014 pasal 1 ayat 1 tentang usia yang disebut anak yakni usia di bawah 18 (delapan belas) tahun. Hal ini sejalan dengan maksud Undang-Undang Nomor 23 Tahun 2002 itu sendiri bahwa usia di bawah 18 (delapan belas) tahun adalah usia di mana seseorang harus dilindungi. Pada usia ini walaupun anak telah dapat menentukan sendiri langkah perbuatannya berdasarkan pikiran, perasaan, dan kehendaknya, tetapi keadaan sekitarnya dapat mempengaruhi perilakunya. Sedangkan apabila seorang anak telah mencapai usia 18 tahun ia telah mempunyai kesiapan jiwa dan mental dalam menghadapi pengaruh lingkungan dan ia telah dapat bertanggung jawab terhadap pilihannya sehingga undangundang tidak menjadikan usia ini sebagai patokan usia anak yang harus dilindungi. Dan pada usia 18 tahun seorang anak sudah diakui melakukan perbuatan hukum dan ia pun telah dikenakan hukum apabila melakukan pelanggaran hukum.

Berkaitan dengan kedudukan anak di mata hukum dikenal istilah anak sah dan anak tidak sah. Hal ini dapat kita lihat dalam ketentuan pasal 42-49 Undang-Undang Nomor 1 Tahun 1974 memberikan defenisi tentang anak dari segi kedudukan seorang anak di mata hukum sebagai berikut:

1. Anak sah

Anak sah adalah anak yang dilahirkan dalam atau sebagai akibat perkawinan yang sah.

Yang dimaksud dengan perkawinan yang sah adalah apabila perkawinan dilakukan menurut hukum agama dan kepercayaan pihak-pihak yang melangsungkan perkawinan. Dan dalam Islam terdapat rukun dan syarat perkawinan yang harus dipenuhi untuk dapat dinilai perkawinan tersebut sah menurut agama Islam.

Selanjutnya pasal 99 Kompilasi Hukum Islam memberikan batas yang lebih luas dan jelas tentang anak sah, yakni anak sah tidak saja anak yang lahir dalam atau akibat perkawinan yang sah, tetapi juga anak yang merupakan hasil pembuahan suami isteri yang sah di luar rahim dan dilahirkan oleh isteri tersebut. (Departemen Agama RI, 1996: t.h.)

2. Anak luar kawin

Dalam penjelasan pasal 186 Kompilasi Hukum Islam, disebutkan bahwa yang dimaksud dengan anak yang lahir di luar perkawinan adalah anak yang dilahirkan di luar perkawinan yang sah atau akibat hubungan yang tidak sah. Maksudnya perkawinan yang dilakukan tidak memenuhi 
rukun dan syarat sahnya perkawinan menurut ketentuan agama atau hubungan yang dilakukan di luar ikatan perkawinan (zina).

Dengan demikian kedudukan anak di mata hukum tergantung kepada status perkawinan orang tuanya. Terhadap perkawinan yang sah, anak mempunyai hubungan keperdataan dengan ayah dan ibunya, sedangkan anak yang lahir di luar perkawinan yang sah hanya mempunyai hubungan nasab dengan ibunya dan keluarga ibunya (pasal 100 Kompilasi Hukum Islam) (Manan, 2002: 353). Sehingga terhadap anak yang lahir di laur perkawinan yang sah hukum hanya diakui sebagai anak ibunya, dan bukan anak dari ayahnya. Sekalipun jelas laki-laki yang bersangkutan yang telah menghamili ibunya sehingga menghadirkan ia ke dunia ini.

Hal ini tentu saja akan mempengaruhi hak dan kewajiban orang tua terhadap anak begitu pula sebaliknya. Misalnya saja hilangnya hak ayah sebagai wali terhadap anak perempuannya dan hilangnya hak saling mewarisi antara orang tua dan anaknya.

\section{Hak-Hak Anak Menurut Hukum Positif di Indonesia}

Dalam Undang-Undang Republik Indonesia Nomor 4 tahun 1979 tentang Kesejahteraan Anak pada Bab II dijelaskan tentang hak-hak yang diperoleh seorang anak yaitu:

Pasal 2: (1)

Anak berhak atas kesejahteraan, perawatan, asuhan dan bimbingan berdasarkan kasih sayang baik dalam keluarganya maupun dalam asuhan khusus untuk tumbuh dan berkembang dengan wajar.

Pasal 2: (2)

Anak berhak atas pelayanan untuk mengembangkan kemampuan dan kehidupan sosialnya, sesuai dengan kebudayaan dan kepribadian bangsa, untuk menjadi warga negara yang baik dan berguna.

Pasal 2: (3)

Anak berhak atas pemeliharaan dan perlindungan, baik semasa dalam kandungan maupun sesudah dilahirkan.

Pasal 2: (4)

Anak berhak atas perlindungan terhadap lingkungan hidup yang dapat membahayakan atau menghambat pertumbuhan dan perkembangannya dengan wajar.

Peraturan perundang-undangan yang lain yang juga menyebutkan hak-hak seorang anak adalah Undang-Undang Nomor 23 Tahun 2002 tentang perlindungan anak, yaitu:

Pasal 4:

Setiap anak berhak untuk dapat hidup, tumbuh, berkembang, dan berpartisipasi secara wajar sesuai dengan harkat dan martabat kemanusiaan, serta mendapat perlindungan dari kekerasan dan diskriminasi.

Pasal 5:

Setiap anak berhak atas suatu nama sebagai identitas diri dan status kewarganegaraan.

Pasal 6:

Setiap anak berhak untuk beribadah menurut agamanya, berpikir, dan berekspresi sesuai dengan tingkat kecerdasan dan usianya, dalam bimbingan orang tua.

Pasal 7: (1)

Setiap anak berhak untuk mengetahui orang tuanya, dibesarkan dan diasuh oleh orang tuanya sendiri.

Pasal 7: (2)

Dalam hal karena suatu sebab orang tuanya tidak dapat menjamin tumbuh kembang anak, atau anak dalam keadaan terlantar maka anak tersebut berhak diasuh atau diangkat sebagai anak asuh atau anak angkat oleh orang lain sesuai dengan ketentuan peraturan perundangundangan yang berlaku. 
Pasal 8:

Setiap anak berhak memperoleh pelayanan kesehatan dan jaminan sosial sesuai dengan kebutuhan fisik, mental, spiritual, dan sosial.

Pasal 9: (1)

Setiap anak berhak memperoleh pendidikan dan pengajaran dalam rangka pengembangan pribadinya dan tingkat kecerdasannya sesuai dengan minat dan bakatnya.

Pasal 9: (2)

Selain hak anak sebagaimana dimaksud dalam ayat (1), khusus bagi anak yang menyandang cacat juga berhak memperoleh pendidikan luar biasa, sedangkan bagi anak yang memiliki keunggulan juga berhak mendapatkan pendidikankhusus.

Pasal 10:

Setiap anak berhak menyatakan dan didengar pendapatnya, menerima, mencari, dan memberikan informasi sesuai dengan tingkat kecerdasan dan usianya demi pengembangan dirinya sesuai dengan nilai-nilai kesusilaan dan kepatutan.

Pasal 11:

Setiap anak berhak untuk beristirahat dan memanfaatkan waktu luang, bergaul dengan anak yang sebaya, bermain, berekreasi, dan berkreasi sesuai dengan minat, bakat, dan tingkat kecerdasannya demi perkembangan diri.

Pasal 13: (1)

Setiap anak selama dalam pengasuhan orang tua, wali, atau pihak lain mana pun yang bertanggung jawab atas pengasuhan, berhak mendapat perlindungan dari perlakuan:
a. Diskriminasi;
b. Eksploitasi, baik ekonomi maupun seksual;
c. Penelantaran;
d. Kekejaman, kekerasan, dan penganiayaan;
e. Ketidakadilan;
f. Perlakuan salah lainnya.

Pasal 13: (2)

Dalam hal orang tua, wali atau pengasuh anak melakukan segala bentuk perlakuan sebagaimana dimaksud dalam ayat (1), maka pelaku dikenakan pemberatan hukuman.

Pasal 14:

Setiap anak berhak untuk diasuh oleh orang tuanya sendiri, kecuali jika ada alasan dan/atau aturan hukum yang sah menunjukkan bahwa pemisahan itu adalah demi kepentingan terbaik bagi anak dan merupakan pertimbangan terakhir.

Pasal 15:

Setiap anak berhak meperoleh perlindungan dari:

a. Penyalahgunaan dalam kegiatan politik;

b. Pelibatan dalam sengketa bersenjata;

c. Perlibatan dalam kerusuhan sosial;

d. Perlibatan dalam peristiwa yang mengandung unsur kekerasan;

e. Perlibatan dalam peperangan.

Pasal 16: (1)

Setiap anak berhak memperoleh perlindungan dari sasaran penganiayaan, penyiksaan, atau penjatuhan hukuman yang tidak manusiawi.

Pasal 16: (2)

Setiap anak berhak untuk memperoleh kebebasan sesuai dengan hukum.

Pasal 16: (3)

Penangkapan, penahanan, atau tindak pidana penjara anak hanya dilakukan apabila sesuai dengan hukum yang berlaku dan hanya dapat dilakukan sebagai upaya terakhir.

Pasal 17: (1)

Setiap anak yang dirampas kebebasannya berhak untuk:

a. Mendapatkan perlakuan secara manusiawi dan penempatannya dipisahkan dari orang dewasa;

b. Memperoleh bantuan hukum atau bantuan lainnya secara efektif dalam setiap tahapan upaya hukum yang berlaku;

c. Membela diri dan memperoleh keadilan di depan pengadilan anak yang objektif dan tidak memihak dalam sidang tertutup untuk umum 
$218 \|$

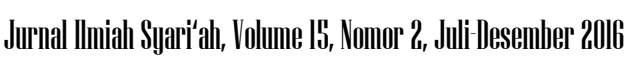

Pasal 17: (2)

Setiap anak yang menjadi korban atau pelaku kekerasan seksual atau yang berhadapan dengan hukum berhak dirahasiakan.

Pasal 18 :

Setiap anak yang menjadi korban atau pelaku tindak pidana berhak mendapatkan bantuan hukum dan bantuan lainnya.

Dari uraian di atas dapat disimpulkan hak asasi anak tersebut berupa:

a. Nondiskriminasi;

b. Kepentingan yang terbaik bagi anak, maksudnya dalam semua tindakan yang menyangkut anak yang dilakukan oleh pemerintah, masyarakat, badan legislatif, dan badan yudikatif, maka kepentingan yang terbaik bagi anak harus menjadi pertimbangan utama;

c. Hak untuk hidup, kelangsungan hidup, dan perkembangan; maksudnya hak asasi yang paling mendasar bagi anak yang dilindungi oleh negara, pemerintah, masyarakat, keluarga, dan orang tua.

Salah satu hak anak yang paling mendasar adalah kejelasan identitas dan statusnya di mata hukum. Identitas dan status yang dimaksud terkait dengan bunyi pasal 4249 Undang-Undang Nomor 1 Tahun 1974 yang menyebutkan adanya anak sah dan anak luar kawin.

Sebagaimana yang telah dijelaskan sebelumnya bahwa anak sah adalah anak yang dilahirkan dalam atau sebagai akibat perkawinan yang sah. Dalam perkawinan yang sah, identitas dan status si anak jelas bahwa ia adalah anak dari bapak dan ibunya. Sedangkan bagi anak lahir di luar perkawinan yang sah identitas dan status si anak tidak jelas, kecuali ia hanya dinasabkan kepada ibunya.

d. Penghargaan terhadap pendapat anak; maksudnya penghormatan atas hak-hak anak untuk berpartisipasi dan menyatakan pendapatnya dalam pengambilan keputusan terutama jika menyangkut hal-hal yang mempengaruhi kehidupannya (Tim penyusun buku UU RI No. 23 Th. 2002, 2008:35).

Upaya perlindungan terhadap hak asasi anak tersebut perlu dilaksanakan sedini mungkin, yakni sejak dari janin dalam kandungan sampai anak berumur 18 tahun. Tindakan ini dimaksudkan untuk mewujudkan kehidupan terbaik bagi anak yang diharapkan sebagai penerus bangsa dan orang tua, keluarga, dan masyarakat bertanggung jawab untuk menjaga dan memelihara hak asasi anak tersebut sesuai dengan kewajiban yang dibebankan oleh hukum positif di Indonesia.

\section{Kewajiban dan Hak Orang Tua terhadap Anak}

Yang dimaksud dengan orang tua adalah ayah dan/atau ibu kandung, atau ayah dan/ atau ibu tiri, atau ayah dan/atau ibu angkat. (Tim penyusun buku UU RI No. 23 Th. 2002, 2008:4)

Ayah dan Ibu (orang tua) adalah yang pertama-tama dapat mewujudkan kesejahteraan anak, baik secara rohani, jasmani, maupun sosial. Sebagai lingkungan sosial pertama yang di kenal anak, orang tua bertanggung jawab memberikan asuhan dan bimbingan kepada si anak.

Sebagaimana yang tercantum dalam Undang-Undang Nomor 1 Tahun 1974 pasal 45 disebutkan kewajiban orang tua, yakni: kedua orang tua wajib memelihara dan mendidik anakanak mereka sebaik-baiknya. Kewajiban ini berlaku sampai anak tersebut kawin atau dapat berdiri sendiri.

Dari kewajiban orang tua, lahirlah hak-hak yang didapat diperoleh oleh seorang anak dari orang tua. Wahbah az Zuhayly menyebutkan 5 hak tersebut yakni:

\section{Nasab}

Wahbah az Zuhayly menjelaskan sebab ditetapkannya nasab seorang anak pada ibunya 
adalah adanya kelahiran, baik kelahiran itu akibat persetubuhan yang sesuai dengan syara' maupun karena persetubuhan yang menyalahi syara'. Sedangkan penetapan nasab seorang anak terhadap ayahnya, disebabkan karena salah satu dari empat hal, yakni:

1. Karena perkawinan yang sah,

2. Karena perkawinan yang fasid/rusak,

3. Karena persetubuhan yang subhat, atau

4. Dengan pengakuan nasab.

Kejelasan nasab seorang anak juga berkaitan dengan hak anak yang lain yakni hak kewarisan. Sebagaimana yang dapat kita lihat dalam Alquran Surat An- Nisa' ayat 7:

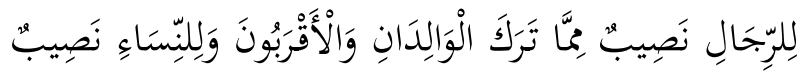

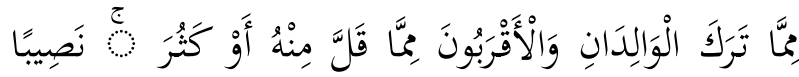

$$
\begin{aligned}
& \text { مَفْرُوضَا }
\end{aligned}
$$

Bagi orang laki-laki ada hak bagian dari harta peninggalan ibu-bapa dan kerabatnya, dan bagi orang wanita ada hak bagian (pula) dari harta peninggalan ibu-bapa dan kerabatnya, baik sedikit atau banyak menurut bahagian yang telah ditetapkan." (Q.S. An-Nisa' [4]: 7)

Di dalam Alquran Surat An-Nisa' ayat 7 ini jelas terlihat bahwa anak-anak baik ia perempuan maupun laki-laki ada hak dan merupakan yang utama di dalam waris.

Dari penelusuran ayat-ayat Alquran tentang kewarisan terlihat bahwa ahli waris yang tidak mungkin mengalami hijab hanyalah anak, ayah, ibu, suami atau istri. (Syarifuddin, 1999: 56) Hal ini senada dengan bunyi Pasal 174 ayat (2): "Apabila semua ahli waris ada, maka yang berhak mendapat warisan hanya : anak, ayah, ibu, janda atau duda."

\section{Radaah (Susuan)}

Ulama figh mendefenisikan radaah dengan, masuknya air susu manusia kedalam perut seorang anak yang umurnya tidak lebih dari dua tahun. "artinya, anak-anak yang dikatakan menyusu adalah anak yang belum mencapai umur dua tahun. Sampai usia dua tahun, perkembangan biologis anak yang sangat ditentukan oleh kadar susu yang diterimanya. Dengan demikian, susuan anak kecil pada usia dini sangat berpengaruh dalam perkembangan fisik mereka.

Menurut Jumhur selain Hanafi rukun radha' ada tiga yakni:

1. Yang menyusui (wanita yang menyusukan)

2. Susu (kadar air susu)

3. Yang disusui (anak yang disusukan). (Dahlan, 2000:1470)

\section{Hadhanah (Pemeliharaan)}

Hadhanah secara bahasa adalah memeluk dan memelihara anak. Sedangkan secara terminologi hadhanah berarti pendidikan terhadap anak bagi yang mempunyai hak dalam pemeliharaan (hadhanah) tersebut, atau pendidikan dan pemeliharaan terhadap seseorang yang masih kecil umurnya atau yang belum mampu membedakan baik dan buruk seperti anak-anak atau orang dewasa yang gila. Hal demikian itu untuk memelihara kelangsungan hidup orang yang dipelihara.

Hak hadhanah adalah salah satu dari beberapa hak anak yang terpikul di atas pundak orang tuanya, dan hak hadhanah merupakan salah satu hak yang terkait dengan hak nasab. Tanpa diakuinya hak nasab seorang anak oleh ayahnya, maka ia tidak akan mendapatkan hak hadhanah secara sempurna, karena hanya akan dilaksanakan oleh pihak ibu.

\section{Walayah (Perwalian/Perlindungan)}

Ulama figh mendefenisikan wilayah dengan wewenang seseorang untuk bertindak hukum atas orang yang tidak bertindak hukum, baik untuk kepentingan pribadinya maupun untuk kepentingan hartanya, yang diizinkan oleh syara". Orang yang masih dalam status ahliyah alwujub, belum dan tidak cakap untuk bertindak 
hukum sendiri, perlu dibantu oleh seseorang yang telah dewasa dan cerdas dalam mengayomi pribadinya dan hartanya. Orang yang membantu mengelola harta dan mengayomi orang yang belum atau tidak cakap bertindak hukum ini, dalam figh Islam disebut wali. (Dahlan, 2000:1934)

Ulama figh menetapkan urutan orangorang yang berhak menjadi wali sebagai berikut:

1. Anak laki-laki, cucu laki-laki, dan seterusnya sampai ke bawah.

2. Ayah, kakek, dan seterusnya sampai ke atas.

3. Saudara laki-laki, anak laki-laki dari saudara laki-laki dan seterusnya sampai ke bawah.

4. Paman, anak laki-laki paman, dan seterusnya sampai ke bawah. (Dahlan, 2000: 1935)

\section{Nafkah}

Secara bahasa nafkah berarti segala sesuatu yang diberikan oleh manusia (terhadap orang miskin dan fakir) atau untuk mencukupkan belanja keluarganya. Secara terminologi yang dimaksud dengan nafkah adalah pemenuhan kebutuhan baik itu makanan, pakaian, dan tempat tinggal.

Wahbah az-Zuhayly membagi nafkah itu kepada dua, yakni:

1. Nafkah yang wajib diberikan manusia kepada dirinya sendiri. Menurut Wahbah nafkah ini harus didahulukan dari pada nafkah yang lain.

2. Nafkah yang harus diberikan manusia kepada selain dirinya dan kewajiban tersebut disebabkan oleh 3 hal:
a. Perkawinan
b. Karib kerabat
c. Kepemilikan.

Hak nafkah ini saling terkait dengan masing-masing hak yang telah disebutkan di atas. Untuk menunaikan tugas radaah, ibu memerlukan pembiayaan. Untuk menunaikan tugas hadhanah, dan begitu pula untuk menunaikan tugas perwalian, terutama perwalian untuk pemeliharaan, pendidikan anak, dan perwalian nikah, semuanya itu memerlukan pembiayaan.

Menurut para ahli figh, orang pertama yang bertanggung jawab atas nafkah anak dalam halhal tersebut adalah kerabat dekat dalam garis nasab, yaitu ayah kandungnya. Maka orang yang tidak diakui nasabnya, berarti kehilangan haknya untuk mendapatkan nafkah dari pihak ayah.

Dalam Undang-Undang Nomor 1 Tahun 1974 pasal 46 disebutkan kewajiban anak kepada orang tua sebagai berikut:

1. Anak wajib menghormati orang tua dan mentaati kehendak mereka yang baik.

2. Jika anak telah dewasa, ia wajib memelihara menurut kemampuannya, orang tua dan keluarga dalam garis lurus ke atas, bila mereka itu memerlukan bantuannya.

Dengan demikian seharusnya sikap seorang anak terhadap orang tua adalah:

1. Mentaati semua perintah dan larangan kedua orangtua, selama di dalamnya tidak terdapat kemaksiatan kepada Allah Swt. dan pelanggaran terhadap syari'atnya

2. Menghormati dan menghargai keduanya, merendahkan suara dan memuliakan keduanya dengan perkataan dan perbuatan yang baik, tidak menghardik dan tidak mengeraskan suara di atas suara keduanya, tidak memanggil keduanya dengan namanya, tidak berpergian kecuali atas izin dan kerelaan keduanya.

3. Menyambung hubungan kekerabatan dari jalur keduanya, mendoakan dan memintakan ampunan untuk keduanya, melaksanakan janji (wasiat) keduanya, dan memuliakan teman-teman atau tamu-tamu keduanya.

\section{PENUTUP}

Anak merupakan titipan Allah Swt yang harus dijaga dengan baik dan harus diberikan 
perlindungan serta penghidupan yang layak. Dengan adanya pengaturan tentang anak yang dirangkum kedalam undang-undang membuat lebih jelas bagaimana kedudukan seorang anak dimata hukum, kemudian hak-hak anak yang harus dipenuhi oleh orang tua serta kewajiban yang harus dilakukan oleh orang tua untuk membuat anak lebih baik. Sehingga kita sebagai orang tua menjadi peran yang baik dimata anak jika menjalankan semua kewajiban dan memberikan hak-hak yang wajib diperoleh oleh seorang anak.

\section{DAFTAR KEPUSTAKAAN}

Andi Syamsu Alam, Fauzan, 2008. Hukum Pengangkatan Anak Prespektif Islam., Jakarta: Pen.

Dahlan Abdul Aziz. 2000. Ensiklopedi Hukum Islam Jilid5. Jakarta: PT Ichtiar Baru van Hoeve.

Departemen Agama Republik Indonesia.2002 AlQuran dan Terjemahan., Jakarta :Pena Pundi Aksara.
Undang-Undang Perlindungan Anak (UU RI No. 23 Th. 2002).Cet. Ketiga. 2008. Jakarta: Sinar Grafika

Departemen Agama RI. 1995/1996. Kompilasi Hukum Islam di Indonesia., Jakarta: Direktorat Jendral Pembinaan Kelembagaan Agama Islam

Manan Abdul. 2002 Pokok-Pokok Hukum Perdata Wewenang Peradilan Agama.Jjakarta: PT. Raja Grafindo Persada, 2002

Mulyadi Lilik. 2005. Pengadilan Anak di Indonesia "(teori, praktik dan permasalahannya)". Bandung:Mandar Maju.

Sumiarni ndang. 2000. Perlindungan Hukum Terhadap Anak dibidang Kesejahteraan. Yogyakarta:Universitas Atma Jaya.

Syarifuddin Amir. 1999. Permasalahan Dalam Pelaksanaan Faraid.Padang: IAIN IB Press

Undang-Undang Perlindungan Anak (UU RI No. 23 Th. 2002).Cet. Ketiga. 2008. Jakarta: Sinar Grafika

Undang-Undang Perkawinan (UURINo.1 Th. 1974)

Undang-Undang Perlindungan Anak (UU RI No. 35 Th. 2014) 